\title{
Aromatic profiles of young wines from berries at different heights on grapevines
}

\author{
Sha XIE ${ }^{1}$, Fan $\mathrm{HU}^{1}$, Changzheng SONG ${ }^{1}$, Zhumei XI ${ }^{1,2 *}$, Zhenwen $\mathrm{ZHANG}^{1,2 * *}$
}

\begin{abstract}
The differences among young wines from berries at 3 heights (fruit-zone 1 (FZ1): 140-200 cm above the ground; FZ2: 80-140 cm; FZ3: $20-80 \mathrm{~cm}$ ) on Vitis vinifera L.cv Merlot and Chardonnay were assessed to evaluate the influence of berry-heights on the final wine quality. Stir bar sorptive extraction coupled with gas chromatography-mass spectrometry (SBSE-GC/MS) was used to analyse the characteristics of wine aromas. The results revealed that berry-heights exert significant influence on ethyl octanoate, isoamyl acetate, ethyl hexanoate, and ethyl butanoate in various- FZ Merlot wines and beta-damascenone in the Chardonnay -FZ wines. As a result, FZ1 wines of Merlot are more aromatic than the other FZ wines and had the highest floral and fruity series intensity. For the Chardonnay wines, fruity and sweet series were highly intense in the FZ1 wines. The PCA results demonstrated a high degree of differences in the aroma of various- FZ wines of the 2 grape cultivars, especially the Merlot variety, which indicates a need to separate the berries from the different- FZs. These results suggest that wineries should consider the possibility of separating berries from different-heights to produce wines of distinctive quality. Furthermore, this knowledge about the volatile composition of young wines offers a means of evaluating the aroma potential of wines from berries taking into account their position along the vines.
\end{abstract}

Keywords: berries of different- heights; wine aromatic compounds; Principal Component Analysis (PCA); odour activity values (OAVs).

Practical Application: There are significant differences in the aromas of wines produced from berries at various heights on vines, indicating that wineries should consider separating berries from different-heights to produce wines of different quality.

\section{Introduction}

As a significant organoleptic characteristic, aroma is vital for determining the quality and typicality of wines (Perestrelo et al., 2006). Its variation not only depends on grape varieties but the surroundings and viticulture practices, such as the training system, harvest date and canopy management (Reynolds et al., 2004; Gomez-Miguez et al., 2007 b; Meyers et al., 2013). The training system can affect the leaf areas exposed to sunlight during berry development, hereby influence fruit maturation and alter wine aroma profile (Gonzalez-Barreiro et al., 2014). For instance, Zoecklein et al. (2008) found that the Geneva double curtain (GDC) training, which is characterized by increasing fruit-zone (FZ) interception of sunlight, conferred higher fruity and floral aromas to wines compared to other pruning systems.

For most training system, it is impossible to maintain absolutely consistent fruit height, for example, in Fan training system, Vertical Shoot Position (VSP) and Vertical independent long-stem pruning (VILSP), the grape berries are all positioned at different-heights along the vines (Cheng et al., 2015). According to previous studies, different grape berries on a single vine may be subject to different light microclimates (Pereira et al., 2006), because these different- height sections receive different amounts of sunlight radiation (Grifoni et al., 2008). Generally grape berries and their chemical compounds are sensitive to microclimate(Bureau et al., 2000; Hernandez-Orte et al.,
2015). Even on the same cultivars, berries exhibit differences in aroma compounds between the tips and shoulders of clusters due to the different amounts of sunlight between the locations (Noguerol-Pato et al., 2012; Figueiredo-Gonzalez et al., 2013). Moreover, grape berry composition has strong relationship with wine characters (Rocha et al., 2007). Therefore, we hypothesize that wines from grape clusters at various- heights alone vines may also exhibit differences in volatile compounds. However, no study has examined this question to date.

The production of uniform parcels of fruit is the primary goal of grapevine cultivation. However, variability within vineyards makes this difficult to achieve (Bramley et al., 2011), so some researchers have proposed the manufacture of wines of different- quality (Noguerol-Pato et al., 2012; Figueiredo-Gonzalez et al., 2013). Wine elaboration guarantees quality and prevents adulteration, and the demands of the global wine market for wines with particular and distinctive characteristics must be met (López de Lerma et al., 2013). However, the effectiveness of this strategy depends on the degree of characterizing differences between wines from various fruit parcels. Previous studies concerning the classification of wines of different- quality have mainly focused on zonal vineyard management (Bramley, 2005), separating the clusters from the tips and shoulders to produce different wines (Noguerol-Pato et al., 2012) and the optimization of fermentation 
practices (Pardo et al., 1999). However, to our knowledge, there have been very few studies of the making of wines of different quality from berries at various- heights on the vines.

In this paper, the berries of two grape varieties (Vitis vinifera L.cv Merlot and Chardonnay) were separated from different-height fruit-zones under VILSP to evaluate the influence of grape berry-height on final wine aroma. The purpose was to provide theoretical guidance to wine-makers for the production of wines with different qualities from the different-height berries on the vines. Furthermore, this knowledge about the volatile composition of young wines offers a means of evaluating the aroma potential of wines from berries taking into account their position along the vines.

\section{Materials and methods}

\subsection{Experimental vineyard}

Field trials were performed at Yuquanying Farm $\left(105^{\circ} 45 \sim 106^{\circ} 47^{\prime} \mathrm{E}, 37^{\circ} 43^{\prime} \sim 39^{\circ} 23^{\prime} \mathrm{N}\right)$, Yongning County, China, which is planted with Vitis vinifera L.cv Merlot and Chardonnay. The region receives strong solar radiation over long sunshine durations, for approximately $3000 \mathrm{~h}$ of sunshine per year. The annual mean rainfall over the last 50 years has been $193.4 \mathrm{~mm}$, but the amount of the rainfall generally declines during the maturation season from August to September when the hydrothermal coefficient ( $\mathrm{K}$ value) averages $0.58-0.83$. The vineyard is managed according to standard agronomic practices of the region. Since 1998 , vines have been planted in rows oriented north-south, with $0.6 \mathrm{~m} \times 3.0 \mathrm{~m}$ spacing, and they have been trained by VILSP.

\subsection{Experimental design}

Experimental treatments were arranged in a randomized complete block design. Based on the fruiting characteristics of Vitis vinifera L.cv Merlot and Chardonnay under VILSP, the FZ- heights were classified as follows for both cultivars: FZ1, $140-200 \mathrm{~cm}$ above the ground; FZ2, 80-140 cm; FZ3, 20-80 cm. For each variety, vines with consistent growth vigour were selected from 3 adjacent rows with each row as a replicate. Each replicate was comprised of 20 vines, so 60 vines from 3 replicates were selected for each variety. Every selected vine was artificially divided into three different positions (FZ1, FZ2 and FZ3) and labelled.

\subsection{Berry maturity coefficient and sampling}

Beginning with veraison, sampling was performed every 7 to 10 days, and soluble sugar (glucose, g/L) content and total acidity (tartaric acid, g/L) were measured. When the content of soluble sugars reached $160 \mathrm{~g} / \mathrm{L}$, sampling was changed to every 3 days and the soluble sugars and total acidity measurements were conducted in triplicate. The optimal harvesting time is determined by the maturity coefficient, which is expressed as the ratio of soluble sugars to total acidity (Coelho et al., 2007). Therefore, Merlot was picked on September 15 and Chardonnay on September 10, 2013.

At the time of commercial harvest of each variety, $3 \times 50 \mathrm{~kg}$ of berries of per FZ of each variety were randomly harvested by hand from the $3 \times 20$ vines which have been labelled before. To ensure that the samples were representative, the number of berries per bunch and the balance between shade and sun in the vineyard were considered. The $3 \times 100$-berry subsamples of per FZ of each variety were crushed into juice by hand for the analysis of the soluble solids and total acids, and additional sub-samples, $3 \times 25 \mathrm{~kg}$ per $\mathrm{FZ}$ of each variety, were used for small-scale winemaking.

\subsection{Small-scale winemaking}

A total of 18 different wines were made from the berries from 3 different- FZs of the 2 selected grape varieties using 25- kg grape samples per FZ of each variety and 3 replicates per FZ of each variety. The standardised process for making red wines (Merlot) followed the method described by Meng et al. (2015). In short, the grapes were destemmed and crushed in a squeezing roller for de-stemming, and the obtained must was transferred to the glass fermentation vessels of $20 \mathrm{~L}$. Sulfur dioxide $(50 \mathrm{mg} / \mathrm{L})$ and pectinase ( $30 \mathrm{mg} / \mathrm{L}$, Lallzyme Ex, Lallemand, France) were added to the grape must. After maceration for $24 \mathrm{~h}$ at room temperature, commercial Saccharomyces cerevisiae (strain RC212, Lavlin, France) was applied in the must to start the fermentation, and alcoholic fermentation was carried out at $20^{\circ} \mathrm{C}$ to $25^{\circ} \mathrm{C}$ until residual sugar content was below $2 \mathrm{~g} / \mathrm{L}$. At the end of alcoholic fermentation, the wines were separated from pomace and free $\mathrm{SO}_{2}$ was adjusted to $50 \mathrm{mg} / \mathrm{L}$ immediately. Chardonnay wines were made according to the standard dry white wine-making procedure without skin contact described by Li et al. (2008). After crushing the grapes, the juices were separated from the pomace. Sulfur dioxide (45 mg/L) and pectinase (20 mg/L, Lallzyme Ex, Lallemand, France) were added to the white juice. After settling about $24 \mathrm{~h}$ at $10-12^{\circ} \mathrm{C}$, fermentation was performed at $18-20^{\circ} \mathrm{C}$.

\subsection{Oenological variables}

The general oenological parameters, including residual sugar, total acid, alcohol by volume, $\mathrm{pH}$, and volatile acid were analyzed according to the methods established by the International Organisation of Vine and Wine (2014).

\subsection{Analysis of volatile compounds}

\section{SBSE sampling conditions}

Aromatic compounds were extracted by the stir bar sorptive extraction (SBSE) technique, which had been previously validated by our group (Meng et al., 2015). Prior to extraction, a stir bar phase-coated with polydimethylsiloxane (PDMS Twister: $1 \mathrm{~cm}$ in length, $0.5 \mathrm{~mm}$ in thickness; Gerstel Inc., Baltimore, MD, USA) was cleaned with a mixture of methanol and dichloromethane (v/v of $1: 1$ ) and conditioned for $30 \mathrm{~min}$ at $280{ }^{\circ} \mathrm{C}$ in a nitrogen atmosphere. During the SBSE extraction process, $20 \mu \mathrm{L}$ of internal standard were added to a $20-\mathrm{mL}$ vial containing $10 \mathrm{~mL}$ of wine diluted with $10 \mathrm{~mL}$ of saturated salt water. The pre-conditioned stir bar was placed in the vial and stirred for $3 \mathrm{~h}$ (1000 rpm). After extraction, the stir bar was rinsed with Milli-Q water, dried with tissue paper, and transferred into a thermal desorption tube.

The stir bar was thermally desorbed using a Turbo Matrix thermal desorption system (TurboMatrix 350 Automated 
Thermal Desorber; PerkinElmer, Waltham, MA, USA) with a carrier gas (helium) flow velocity of $45 \mathrm{~mL} / \mathrm{min}$. Desorption was performed for $15 \mathrm{~min}$ at heater valve and desorption tube temperatures of $245^{\circ} \mathrm{C}$ and $270{ }^{\circ} \mathrm{C}$, respectively. The transfer line temperature was maintained at $255^{\circ} \mathrm{C}$, and the cold trap capture temperature was increased from $-30^{\circ} \mathrm{C}$ to $255^{\circ} \mathrm{C}$ at a rate of $40^{\circ} \mathrm{C} / \mathrm{min}$.

\section{GC-MS analysis}

The GC-MS apparatus used in our study was a Trace DSQ GC-MS (Thermo-Finnigan, 'San Jose, CA, USA). Helium, the carrier gas of the chromatographic column $\left(30 \mathrm{~m}^{\star} 0.25 \mathrm{~mm}^{\star} 0.25 \mu \mathrm{m}\right.$ J\&W Scientific, Folsom, CA) flowed at a constant rate of $1 \mathrm{~mL} / \mathrm{min}$. The oven temperature was programmed to hold at $40{ }^{\circ} \mathrm{C}$ for $3 \mathrm{~min}$; it was increased to $160^{\circ} \mathrm{C}$ at $4{ }^{\circ} \mathrm{C} / \mathrm{min}$, then to $230^{\circ} \mathrm{C}$ at $7^{\circ} \mathrm{C} / \mathrm{min}$ and finally maintained at $230^{\circ} \mathrm{C}$ for $8 \mathrm{~min}$. The mass range $(\mathrm{m} / \mathrm{z})$ was $33-450 \mathrm{amu}$ with a $1.0-\mathrm{Hz}$ scanning frequency. The MS transfer line and injection temperatures were set at $230^{\circ} \mathrm{C}$ and $250^{\circ} \mathrm{C}$, respectively, and mass spectra were obtained in the electron impact (EI) mode, in which the electron impact (EI) energy was $70 \mathrm{eV}$ and the ion source temperature was $230{ }^{\circ} \mathrm{C}$ (Li et al., 2008). All of the analyses were conducted in triplicate.

\section{Qualitative analysis and quantification}

Aroma identification was achieved by comparing the GC retention indices and mass spectra with those present in the Standard NIST05 Library or in the literature as well as by analysing pure standards under the same conditions. The quantification of most aroma compounds followed the internal standard-standard curve method, and Octan-2-ol (0.234 g/L) was chosen as the internal standard. The aroma contents were determined through interpolation of the selected mass ion areas against the internal standard area. In addition, volatile compounds without calibration curves were quantified with those standards that had the same functional group and/or similar numbers of $\mathrm{C}$ atoms (Meng et al., 2013).

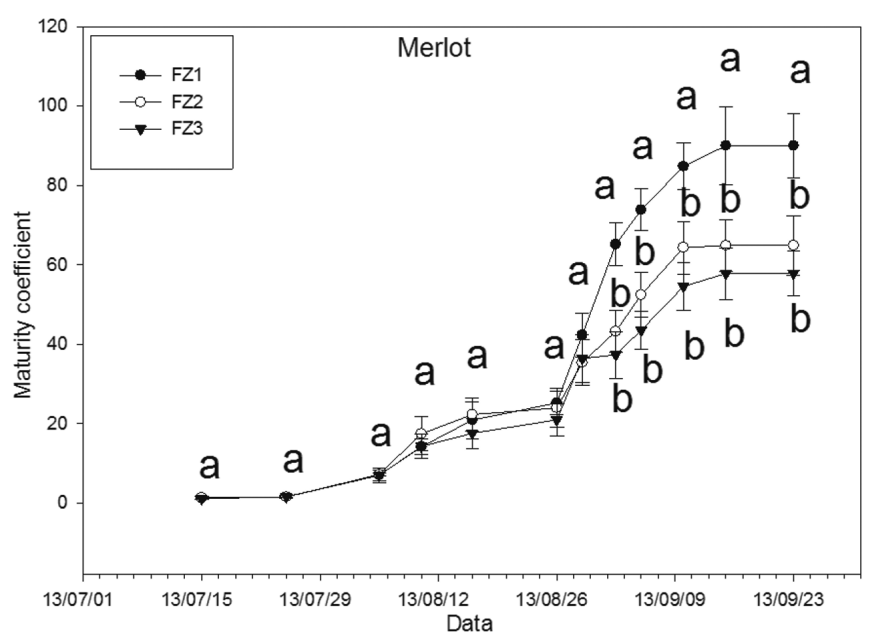

\subsection{Odour activity values (OAVs)}

Odour activity values (OAVs) were determined to evaluate the contribution of the volatile compounds to the wine aroma and calculated as the ratio of the volatile concentration to the perception threshold (Buettner \& Schieberle, 2001). Additionally, the odour descriptor and odour thresholds of the volatiles were obtained from the literature (Moyano et al., 2002; Francis \& Newton, 2005; Jiang et al., 2013).

\subsection{Statistical analysis}

All of the statistical parameters were analysed in SPSS20.0, and the results are expressed as the mean \pm standard deviation of the three triplicate samples. One-way analysis of variance (ANOVA) and the least significant difference (LSD) test were conducted to detect significant differences in the aromas of the different- FZ wines. Principal component analysis (PCA) was used to evaluate the degree of the differences; it was conducted on a correlation matrix that accounted for all of the volatiles.

\section{Results and discussion}

\subsection{Berry maturity coefficient}

The maturation states of the grape berries were monitored (Figure 1), and the results revealed that berries of the 2 grape cultivars grown at different- heights on the vine presented different maturity coefficients, which decreased in the following order: FZ1 > FZ2 >FZ3 for both cultivars. These differences may be attributed to the effect of bunch exposure to sunlight (Keller \& Hrazdina, 1998; Grifoni et al., 2008). Because different- height sections of grapevines received different amounts of sunlight radiation according to previous literatures (Grifoni et al., 2008). Furthermore, various- FZ berries of the Merlot variety showed significant differences in maturity coefficients during the later grape-ripening stages, but there were no significant differences in the Chardonnay variety throughout grape ripening.

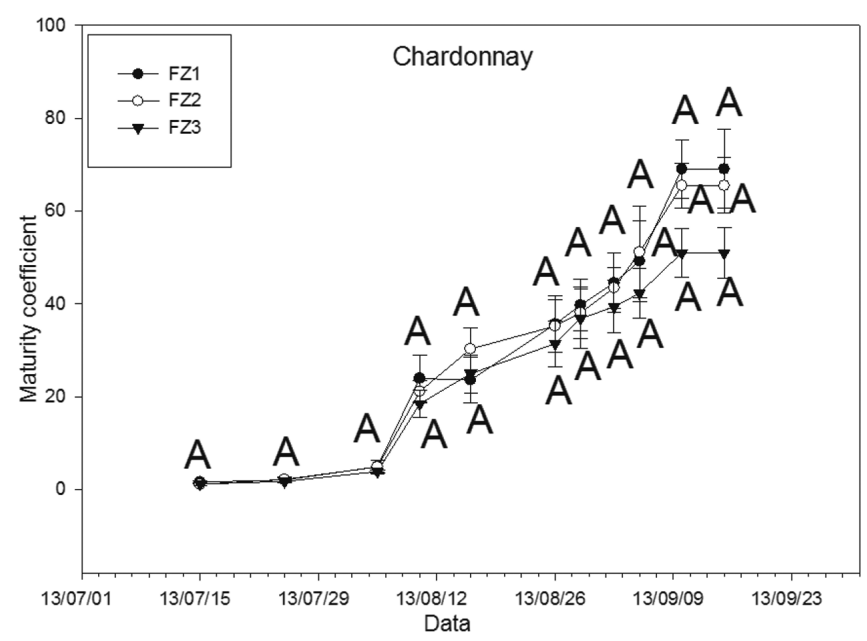

Figure 1. Maturity coefficients of berries from different fruit zones (FZ1: 140-200 cm above the ground; FZ2:80-140 cm; FZ3: 20-80 cm) of 2 grape cultivars. Sampling was performed beginning July 15, 2013 for Merlot and Chardonnay. The maturity coefficient is expressed as the radio of soluble sugars to total acidity. Different letters for the same period indicate significant differences as determined by ANOVA $(\mathrm{P}<0.05)$. 


\subsection{General compositions of grapes and wines}

Increased berry height caused an increase of the total soluble solids of grape must of Merlot and FZ3 berries had significantly lower total soluble solids than other FZs (Table 1). For Chardonnay variety, the berries from various-heights did not differ significantly. This result is partly consistent with the result of maturity coefficients, as Brix is also an indicator reflecting maturation states (Grifoni et al., 2008). Additionally, the total acids increased with decreasing berry height as expected, which was most likely due to the effect of canopy shading (Song et al., 2014).

The wine composition values reflect the characteristics of young dry red and white wines, and indicate a good vinification process according to the International Organisation of Vine and Wine (2012).

\subsection{Volatile compound analysis}

\section{Higher alcohols}

Higher alcohols were the most abundant volatile compounds among all of aroma compounds (Table 2), and they increased by $28.9 \%$ in the FZ2 wines compared to the FZ1 wines in Merlot, which was primarily attributed to a $32.8 \%$ increase in 1 -pentanol. The FZ1 wines were notable for an increase in phenylethyl alcohol and a decrease in 1-hexanol, and this might be a benefit as other studies have demonstrated that phenylethyl alcohol contributes a desirable aroma to wines, whereas 1-hexanol can confer undesirable herbaceous flavours (Bindon et al., 2013; Garde-Cerdán et al., 2015). In the various- FZ Chardonnay wines, there were no marked differences in higher alcohol contents, and no differences were found in any of the individual volatiles in the higher alcohol class. The results imply that berry-height did not exert significant influence on the concentration of higher alcohols of Chardonnay wines.

\section{Volatile esters}

Volatile esters are classified into 3 groups based on their different precursors, namely, acetate esters, ethyl esters and other esters (Nan et al., 2013), among which the acetate esters exhibited the higher concentrations in all samples. In Merlot, the FZ1 wines possessed the greatest abundance of the desired aromas, among which hexyl acetate, phenethyl acetate, and ethyl octanoate were the main contributors. As previous studies have suggested that hexyl acetate, phenethyl acetate, ethyl octanoate, and isoamyl acetate were important compositions determining the quality of wines (Cacho et al., 2013; Cai et al., 2014; Caliari et al., 2015), FZ1 wines of Merlot may benefit from those volatile esters. However, the FZ2 wines were characterized by dramatically high isoamyl acetate contents, which may give FZ2 wines of Merlot pear-drops aroma characters (Swiegers et al., 2005). Ethyl esters were dominant in the FZ3 wines with markedly high levels of ethyl cinnamate and ethyl hexanoate contents, but their degree of influence was inconclusive because most ethyl esters had low thresholds and could intensely affect wine aroma even at low concentration (Gomez-Miguez et al., 2007a). These compounds are only beneficial to wines at low concentrations; at high contents, they produce unfavourable odours of wax and honey (Coetzee \& du Toit, 2012)

Unlike Merlot varieties, the highest volatile ester content occurred in the FZ2 wines of Chardonnay but was lowest in the FZ1 wines and this was mainly due to the significantly differences in ethyl acetate contents among various- FZ. A possible explanation was that prolonged light exposure in FZ1 resulted in excessive loss or degradation of volatiles in white cultivars (Gatti et al., 2015) Furthermore, there are fewer volatile esters that presented significant differences in the various- FZ white wines than in red wines. These results suggest that berry-height exert less effect on volatile esters in Chardonnay wines than in Merlot.

\section{Fatty acids}

Fatty acids were the third most abundant volatiles, and maximum amounts of hexanoic acid, octanoic acid, and $\mathrm{n}$-decanoic acid were simultaneously detected in all of the wines, which supported previous findings (Perestrelo et al., 2006; Coetzee \& du Toit, 2012). Fatty acids have been reported to be able to affect the aromatic equilibrium of wines because they are opposed to the hydrolysis of the corresponding esters. This compound strengthens wine flavor at low concentration, but at high levels, conferred wine sour and thin tasting (Jiang et al., 2013). In our study, n-decanoic acid differed notably in the various-FZ wines of both cultivars and this could be explained

Table 1. General composition ${ }^{\mathrm{a}}$ of grapes and wines from different $\mathrm{FZs}^{\mathrm{b}}$ on the vines of 2 grape cultivars.

\begin{tabular}{|c|c|c|c|c|c|c|}
\hline \multirow{2}{*}{ parameters } & \multicolumn{3}{|c|}{ Merlot } & \multicolumn{3}{|c|}{ Chardonnay } \\
\hline & FZ1 & FZ2 & FZ3 & FZ1 & FZ2 & FZ3 \\
\hline \multicolumn{7}{|l|}{ Grape- must composition } \\
\hline Total soluble solids (Brix) & $22.5 \pm 0.3 \mathrm{a}^{\mathrm{c}}$ & $22.2 \pm 0.1 \mathrm{a}$ & $21.0 \pm 0.4 b$ & $23.1 \pm 0.6 \mathrm{~A}$ & $23.8 \pm 0.4 \mathrm{~A}$ & $22.8 \pm 0.3 \mathrm{~A}$ \\
\hline Total acids (g/L) & $2.50 \pm 0.03 c$ & $3.50 \pm 0.06 b$ & $3.70 \pm 0.04 \mathrm{a}$ & $3.30 \pm 0.03 \mathrm{C}$ & $3.51 \pm 0.04 \mathrm{~B}$ & $3.98 \pm 0.01 \mathrm{~A}$ \\
\hline \multicolumn{7}{|l|}{ Wine composition } \\
\hline Residual sugar (g/L) & $3.45 \pm 0.11 \mathrm{a}^{\mathrm{b}}$ & $2.31 \pm 0.04 b$ & $3.50 \pm 0.20 \mathrm{a}$ & $3.20 \pm 0.21 \mathrm{~A}$ & $2.20 \pm 0.08 \mathrm{~B}$ & $2.20 \pm 0.13 \mathrm{~B}$ \\
\hline $\mathrm{pH}$ & $4.17 \pm 0.02 \mathrm{a}$ & $3.93 \pm 0.05 b$ & $3.79 \pm 0.05 c$ & $3.71 \pm 0.05 \mathrm{~A}$ & $3.75 \pm 0.07 \mathrm{~A}$ & $3.72 \pm 0.06 \mathrm{~A}$ \\
\hline Volatile acid (mg/L) & $0.25 \pm 0.01 \mathrm{a}$ & $0.24 \pm 0.01 \mathrm{a}$ & $0.26 \pm 0.01 \mathrm{a}$ & $0.22 \pm 0.01 \mathrm{~A}$ & $0.25 \pm 0.01 \mathrm{~A}$ & $0.26 \pm 0.01 \mathrm{~A}$ \\
\hline
\end{tabular}

in the same row indicate significant differences determined by ANOVA $(\mathrm{P}<0.05)$ : a, b, c for Merlot and A, B, C for Chardonnay. 
Table 2. Concentrations $(\mu \mathrm{g} / \mathrm{L})^{\mathrm{a}}$ of volatile compounds in wines from berries of different $\mathrm{FZs}$ on the vine of 2 grape cultivars.

\begin{tabular}{|c|c|c|c|c|c|c|c|}
\hline \multirow{2}{*}{ Code } & \multirow{2}{*}{ Compounds } & \multicolumn{3}{|c|}{ Merlot $(\mu \mathrm{g} / \mathrm{L})$} & \multicolumn{3}{|c|}{ Chardonnay $(\mu \mathrm{g} / \mathrm{L})$} \\
\hline & & FZ1 & FZ2 & FZ3 & FZ1 & FZ2 & FZ3 \\
\hline $\mathrm{V} 1$ & 1-Pentanol & $79778.28 \pm 1189.95 \mathrm{a}^{\mathrm{c}}$ & $\begin{array}{c}105936.00 \pm \\
28189.95 \mathrm{a}\end{array}$ & $\begin{array}{c}85167.63 \pm \\
12808.14 \mathrm{a}\end{array}$ & $\mathrm{ND}^{\mathrm{d}}$ & ND & ND \\
\hline $\mathrm{V} 2$ & 1-Hexanol & $31.47 \pm 1.20 \mathrm{~b}$ & $34.80 \pm 1.56 \mathrm{ab}$ & $38.61 \pm 0.54 \mathrm{a}$ & $41.67 \pm 3.03 \mathrm{~A}$ & $33.03 \pm 3.72 \mathrm{~A}$ & $36.84 \pm 0.48 \mathrm{~A}$ \\
\hline V3 & 1-Nonanol & ND & ND & ND & ND & ND & ND \\
\hline \multirow[t]{4}{*}{ V5 } & Isopentanol & ND & ND & ND & $\begin{array}{l}37032.39 \pm \\
47038.44 \mathrm{~A}\end{array}$ & $52612.44 \pm 9435.21 \mathrm{~A}$ & $\begin{array}{l}48483.66 \pm \\
18333.54 \mathrm{~A}\end{array}$ \\
\hline & Subtotal & 85903.95 & 110704.89 & 89930.16 & 86808.90 & 100476.81 & 100664.43 \\
\hline & Subtotal \% & 46.290 & 55.200 & 47.736 & 56.848 & 56.226 & 55.859 \\
\hline & Acetates esters & & & & & & \\
\hline V6 & Ethyl acetate & $48382.47 \pm 3420.18 \mathrm{a}$ & $43869.75 \pm 3120.30 \mathrm{a}$ & $50417.76 \pm 4021.56 \mathrm{a}$ & $23577.99 \pm 319.56 \mathrm{~B}$ & $36904.80 \pm 547.98 \mathrm{~A}$ & $33363.87 \pm 2594.91 \mathrm{~A}$ \\
\hline \multirow{3}{*}{ V9 } & Subtotal & 54617.04 & 50398.68 & 56260.20 & 23855.04 & 37143.36 & 33648.72 \\
\hline & Subtotal \% & 29.431 & 25.130 & 29.863 & 15.622 & 20.785 & 18.672 \\
\hline & Ethyl esters & & & & & & \\
\hline V10 & Ethyl butanoate & $1058.31 \pm 327.27 \mathrm{a}$ & $981.42 \pm 270.54 \mathrm{a}$ & $1100.19 \pm 46.8 \mathrm{a}$ & $330.75 \pm 160.77 \mathrm{~A}$ & $255.00 \pm 59.34 \mathrm{~A}$ & $245.34 \pm 48.03 \mathrm{~A}$ \\
\hline V11 & Ethyl hexanoate & $334.29 \pm 1.11 b$ & $305.94 \pm 1.47 \mathrm{c}$ & $347.55 \pm 4.86 \mathrm{a}$ & $134.76 \pm 11.94 \mathrm{~A}$ & $124.38 \pm 16.41 \mathrm{~A}$ & $146.79 \pm 1.29 \mathrm{~A}$ \\
\hline V12 & Ethyl octanoate & $411.81 \pm 1.62 \mathrm{a}$ & $316.32 \pm 0.96 c$ & $381.06 \pm 0.39 b$ & $142.71 \pm 0.78 \mathrm{~B}$ & $135.36 \pm 0.09 \mathrm{C}$ & $146.49 \pm 1.89 \mathrm{~A}$ \\
\hline V13 & Ethyl decanoate & $93.21 \pm 5.97 \mathrm{a}$ & $71.16 \pm 5.94 \mathrm{~b}$ & $97.80 \pm 5.10 \mathrm{a}$ & $55.20 \pm 0.81 \mathrm{~A}$ & $35.64 \pm 13.20 \mathrm{~A}$ & $58.68 \pm 2.16 \mathrm{~A}$ \\
\hline V14 & $\begin{array}{c}\text { Diethyl } \\
\text { succinate }\end{array}$ & $7807.14 \pm 253.80 \mathrm{a}$ & $7898.22 \pm 254.49 a$ & $6466.80 \pm 149.79 b$ & $8851.14 \pm 481.71 \mathrm{~A}$ & $8205.99 \pm 445.74 \mathrm{~A}$ & $8687.43 \pm 101.94 \mathrm{~A}$ \\
\hline V15 & $\begin{array}{c}\text { Ethyl } \\
\text { cinnamate }\end{array}$ & $5.28 \pm 0.12 b$ & $3.44 \pm 0.08 c$ & $8.01 \pm 0.19 \mathrm{a}$ & ND & ND & ND \\
\hline V18 & acid ethyl ester & & & & & & \\
\hline V19 & $\begin{array}{l}\text { Ethyl hydrogen } \\
\text { succinate }\end{array}$ & ND & ND & ND & $1379.37 \pm 259.29 \mathrm{~A}$ & $1716.69 \pm 7.92 \mathrm{~A}$ & $1674.03 \pm 409.95 \mathrm{~A}$ \\
\hline V20 & Ethyl vanillate & ND & ND & ND & $46.02 \pm 3.24 \mathrm{~A}$ & $38.25 \pm 2.13 \mathrm{~B}$ & ND \\
\hline V21 & $\begin{array}{l}\text { Phenethyl } \\
\text { butyrate }\end{array}$ & ND & ND & ND & ND & ND & ND \\
\hline \multirow[t]{4}{*}{ V22 } & Ethyl salicylate & ND & ND & ND & ND & ND & ND \\
\hline & Subtotal & 10435.35 & 9993.51 & 9354.24 & 11121.93 & 10561.44 & 11008.86 \\
\hline & Subtotal \% & 5.623 & 4.983 & 4.965 & 7.283 & 5.910 & 6.109 \\
\hline & Other esters & & & & & & \\
\hline \multirow[t]{3}{*}{ V23 } & $\begin{array}{l}\text { Isopropyl } \\
\text { Palmitate }\end{array}$ & $0.99 \pm 0.36 \mathrm{a}$ & $0.60 \pm 0.51 \mathrm{a}$ & $1.11 \pm 0.33 \mathrm{a}$ & $0.51 \pm 0.06 \mathrm{~A}$ & $0.75 \pm 0.21 \mathrm{~A}$ & $0.57 \pm 0.15 \mathrm{~A}$ \\
\hline & Subtotal \% & TR & TR & TR & TR & TR & TR \\
\hline & Fatty acids & & & & & & \\
\hline V24 & Hexanoic acid & $4656.93 \pm 222.21 \mathrm{a}$ & $4564.92 \pm 224.73 a$ & $4688.13 \pm 578.94 \mathrm{a}$ & $3175.23 \pm 33.66 \mathrm{~A}$ & $3306.24 \pm 409.86 \mathrm{~A}$ & $3572.34 \pm 269.64 \mathrm{~A}$ \\
\hline V25 & Octanoic Acid & $17223.24 \pm 2610.63 a$ & $16702.17 \pm 2613.66 \mathrm{a}$ & $16021.95 \pm 553.38 \mathrm{a}$ & $6941.28 \pm 5035.41 \mathrm{~A}$ & $9398.97 \pm 553.95 \mathrm{~A}$ & $11595.72 \pm 121.89 \mathrm{~A}$ \\
\hline V26 & Nonanoic acid & $973.23 \pm 26.70 \mathrm{a}$ & $791.85 \pm 22.50 \mathrm{a}$ & $652.14 \pm 144.00 \mathrm{a}$ & $936.48 \pm 126.93 \mathrm{~A}$ & $897.96 \pm 76.17 \mathrm{~A}$ & $848.16 \pm 97.05 \mathrm{~A}$ \\
\hline V27 & $\begin{array}{c}\text { n-Decanoic } \\
\text { acid }\end{array}$ & $10630.44 \pm 364.29 a$ & $6552.51 \pm 329.43 c$ & $8523.45 \pm 202.89 b$ & $11817.96 \pm 5.91 \mathrm{~A}$ & $10012.32 \pm 214.74 \mathrm{~B}$ & $11858.34 \pm 91.08 \mathrm{~A}$ \\
\hline
\end{tabular}


Table 2. Continued...

\begin{tabular}{|c|c|c|c|c|c|c|c|}
\hline \multirow{2}{*}{ Code } & \multirow{2}{*}{ Compounds } & \multicolumn{3}{|c|}{ Merlot $(\mu \mathrm{g} / \mathrm{L})$} & \multicolumn{3}{|c|}{ Chardonnay $(\mu \mathrm{g} / \mathrm{L})$} \\
\hline & & $\mathrm{FZ1}$ & FZ2 & FZ3 & $\mathrm{FZ1}$ & FZ2 & FZ3 \\
\hline V28 & $\begin{array}{c}\text { n-Hexadecanoic } \\
\text { acid }\end{array}$ & $305.55 \pm 121.14 \mathrm{a}$ & $229.65 \pm 109.26 a$ & $395.88 \pm 225.75 a$ & $306.36 \pm 72.30 \mathrm{~A}$ & $477.48 \pm 41.67 \mathrm{~A}$ & $371.73 \pm 213.96 \mathrm{~A}$ \\
\hline V29 & $\begin{array}{c}\text { Dodecanoic } \\
\text { acid }\end{array}$ & ND & ND & $1779.54 \pm 376.26 \mathrm{a}$ & $1488.60 \pm 212.79 \mathrm{~A}$ & $1225.65 \pm 218.40 \mathrm{~A}$ & $1060.14 \pm 417.39 \mathrm{~A}$ \\
\hline V30 & $\begin{array}{l}\text { 9-Decenoic } \\
\text { acid }\end{array}$ & ND & ND & ND & $53.10 \pm 2.37 \mathrm{~A}$ & $55.62 \pm 3.96 \mathrm{~A}$ & $65.16 \pm 4.14 \mathrm{~A}$ \\
\hline V31 & $\begin{array}{c}\text { Tetradecanoic } \\
\text { acid }\end{array}$ & $30.36 \pm 28.77 a$ & $47.67 \pm 37.32 \mathrm{a}$ & $75.57 \pm 61.77 a$ & $57.00 \pm 15.93 \mathrm{~A}$ & $101.67 \pm 4.62 \mathrm{~A}$ & $92.16 \pm 69.21 \mathrm{~A}$ \\
\hline \multirow[t]{4}{*}{ V32 } & $\begin{array}{l}\text { Pentadecanoic } \\
\text { acid }\end{array}$ & $5.97 \pm 3.72 \mathrm{a}$ & $4.14 \pm 2.73 \mathrm{a}$ & $3.72 \pm 2.22 \mathrm{a}$ & $4.5 \pm 1.11 \mathrm{~A}$ & $6.78 \pm 0.09 \mathrm{~A}$ & $4.95 \pm 3.60 \mathrm{~A}$ \\
\hline & Subtotal & 33825.78 & 28892.82 & 32140.38 & 24496.17 & 25236.84 & 29272.74 \\
\hline & Subtotal \% & 18.227 & 14.407 & 17.060 & 16.042 & 14.122 & 16.244 \\
\hline & Terpenes & & & & & & \\
\hline V33 & Geranic acid & $579.18 \pm 55.11 \mathrm{a}$ & $440.19 \pm 55.11 \mathrm{a}$ & $518.13 \pm 37.68 \mathrm{a}$ & ND & ND & ND \\
\hline V34 & Citronellol & $97.80 \pm 7.68 \mathrm{a}$ & $116.04 \pm 7.68 \mathrm{a}$ & $156.87 \pm 27.15 \mathrm{a}$ & ND & ND & ND \\
\hline V35 & Linalool & $118.14 \pm 7.89 \mathrm{a}$ & $6.45 \pm 7.89 b$ & $31.26 \pm 8.97 \mathrm{~b}$ & ND & ND & ND \\
\hline \multirow[t]{3}{*}{ V36 } & Farnesol & ND & ND & ND & $6422.37 \pm 2336.94 \mathrm{~A}$ & $5284.77 \pm 279.12 \mathrm{~A}$ & $5616.54 \pm 995.16 \mathrm{~A}$ \\
\hline & Subtotal & 795.15 & 562.68 & 706.26 & 6422.37 & 5284.77 & 5616.54 \\
\hline & Subtotal \% & 0.428 & 0.281 & 0.375 & 4.206 & 2.957 & 3.117 \\
\hline \multirow{3}{*}{ V37 } & Norisoprenoids & & & & & & \\
\hline & $\begin{array}{c}\text { beta- } \\
\text { damascenone }\end{array}$ & $0.06 \pm 0.02 \mathrm{a}$ & TR & TR & $14.07 \pm 0.69 \mathrm{~A}$ & $8.37 \pm 0.83 \mathrm{~B}$ & $7.86 \pm 0.54 \mathrm{~B}$ \\
\hline & $\begin{array}{c}\text { Subtotal \% } \\
\text { Others }\end{array}$ & TR & TR & TR & 0.010 & TR & TR \\
\hline \multirow[t]{3}{*}{ V38 } & $\begin{array}{l}\text { 2,4,6-Tri-tert- } \\
\text { butylphenol }\end{array}$ & TR & TR & $14.88 \pm 7.32 \mathrm{a}$ & TR & $59.52 \pm 14.64 \mathrm{~A}$ & $25.62 \pm 5.55 \mathrm{~B}$ \\
\hline & Subtotal \% & TR & TR & 0.010 & TR & 0.031 & 0.012 \\
\hline & Subtotal & 185577.27 & 200552.58 & 188391.24 & 152704.41 & 178703.22 & 180211.29 \\
\hline
\end{tabular}

${ }^{\mathrm{a}}$ Values are expressed as the mean \pm standard deviation of the triplicate samples; ${ }^{\mathrm{b}} \mathrm{FZs}$, fruit-zones: FZ1, $140-200 \mathrm{~cm}$ above the ground; FZ2:80-140 cm; FZ3:20-80 cm; ${ }^{\mathrm{c}}$ Different letters in the same row indicate significant differences determined by ANOVA $(\mathrm{P}<0.05)$ : a, b, c for Merlot, and A, B, C for Chardonnay; ${ }^{\mathrm{d} D D}$ : not detected; ${ }^{\mathrm{e}} \mathrm{TR}$ : trace.

by the difference of grape- must composition measured above (Schreier \& Jennings, 1979)

\section{Terpenes}

On the whole, the FZ1 wines of both grape cultivars contained the highest concentrations of terpenes compared to the other FZ wines. Increased exposure to sunlight and grape maturity in FZ1 were most likely associated with the high terpene contents of the FZ1 wines (Song et al., 2014). In addition, previous studies have found most terpenes be beneficial to wine aroma and that they can emit floral fragrances; (Noguerol-Pato et al., 2012; Garde-Cerdán et al., 2015) the FZ1 wines were thus most likely to benefit.

\section{Norisoprenoids}

Of the norisoprenoid compounds, only beta-damascenone was detected in all of the samples. Although beta-damascenone was found in very low concentrations in the FZ1 Merlot wines, it had a significantly positive influence as a result of its low odour threshold (Gomez-Miguez et al., 2007a). In contrast, beta-damascenone occurred in relatively high concentrations in the Chardonnay wines; in particularly, the Chardonnay FZ1 wines contained higher levels than the other FZ wines. These differences in beta-damascenone contents can likely be attribute high sunlight exposure in the FZ1 berries, as previous study reported that sunlight seemed to increase the concentration of carotenoids, which are considered to be precursors of $\mathrm{C} 13$ norisoprenoids (Gonzalez-Barreiro et al., 2014).

\subsection{Principal Component Analysis (PCA)}

PCA was performed to investigate the degree of differences in the characteristics of the wines from various fruit parcels as well as the degree of similarity among wines from the same FZ berries. The analysis was conducted using a correlation matrix accounted for all of the volatiles. In Merlot wines, the first 2 principal components represented approximately $75 \%$ of the cumulative variance (Figure 2). As depicted in the score plots (Figure 2a), the $3 \mathrm{FZ}$ wines were located in different quadrants of the PC1-PC2 plane, indicating that the wines from contrasting FZs were discernibly different while the wines from berries in the same FZ were tightly clustered, which suggests that these wines have consistent aromatic characteristic. These results demonstrated a high degree of aromatic difference between the wines of various-FZ of the Merlot cultivar, indicating the need to differentiate between the wines from the Merlot berries of 

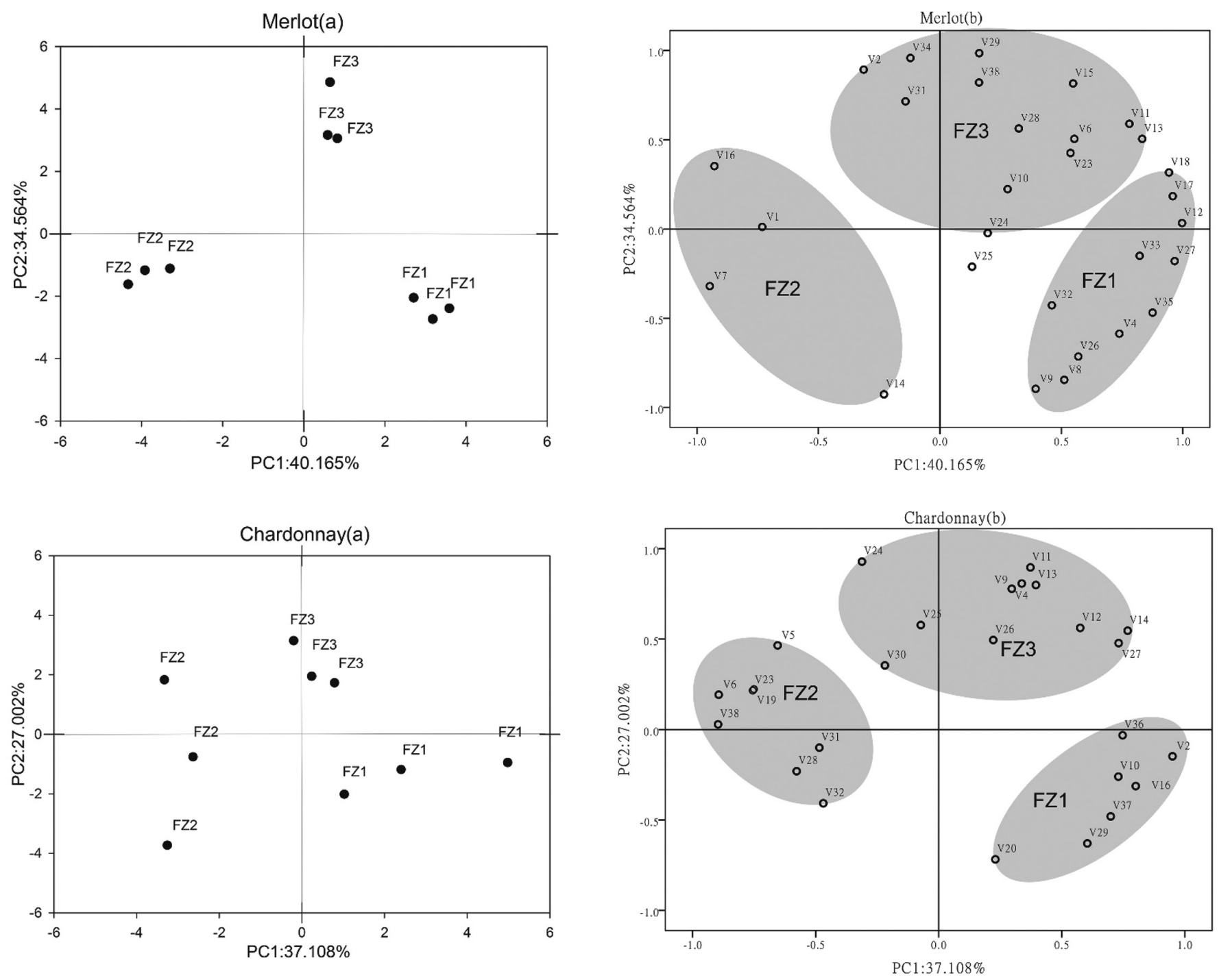

Figure 2. The first 2 principal scatter plots of the wines from the different fruit zones (FZ1: 140-200 cm above the ground; FZ2:80-140 cm; FZ3: $20-80 \mathrm{~cm}$ ) based on all the volatile compounds. (a) The score plot and (b) the corresponding loading plot (the numbers corresponding to each volatile are presented in Table 2).

various-FZ. Otherwise, uniform management might result in the mix of different quality wine. These differences in the volatiles of various- FZ red wines may be related to the significant differences in the degree of maturity mentioned above; as berry ripeness can influence the chemical composition of grapes destined for winemaking (Bindon et al., 2013). In addition, the loading plots (Figure 2b) combined with the loading matrix (Supplementary Material) revealed that the responsible compounds in FZ1 Merlot wines were V4, V8, V9, V26, V32, and V35 (see Table 2 for the individual compounds). They were V1, V7, and V16 for FZ2 and V2, V15, V29, V34, and V38 for FZ3. Overall, most of the volatiles with great potential to introduce difference to the various FZs of the red varieties were fermentative compounds; and this could be related to the different nutrient content of the fermentative must of grapes from various- FZs, such as the difference in these compositions shown in Table 1 (Bell \& Henschke, 2005; Garde-Cerdán et al., 2009).
In the Chardonnay wines, the first 2 principal components only explained $64.115 \%$ of the cumulative variance (Figure 2). Furthermore, the same FZ Chardonnay wines showed greater dispersion on the score plot than the Merlot wines, suggesting that the height of the berries exerted less of an influence on the white grape than on the red ones. A possible explanation is that the white cultivars were not very sensitive to sunlight (Goldberg et al., 1999), but, combined with the loading plot (Figure 2b), the various- FZ wines have different characteristics. Specifically, the FZ1 wines were alone in the fourth quadrant, indicating a strong positive correlation with the PC1 compounds: V2, V16, V29, V36, and V37 (Supplementary Material). Meanwhile, the FZ2 wines fell on the negative side of $\mathrm{PC} 1$, suggesting a relationship with $\mathrm{V} 6$, V19, V23, and V38. The FZ3 wines were clustered around the origin and along PC2, suggesting high positive affinities with V4, V9, V11, V13, and V24. 
Overall, the PCA results demonstrated a high degree of differences in the aroma of various- FZ wines of the 2 grape cultivars, especially the Merlot variety, which indicates a need to separate the berries from the different- FZs. We must admit that our study was carried out in one year only. However, the purpose of this paper is to investigate the effect of berry height along the vines on the wine aroma. The differences of climate and vineyard management from different years are the same for 3-heights berry. Therefore, our results are enough to reflect the significant influence of berry height on wine aroma.

\subsection{Odour activity values (OAVs)}

Volatiles, whose odour activity values (OAVs) are above 1 , are considered to be potent aroma contributors to wines, but due to the influence of additive or synergistic effects between similar volatiles, a compound exhibiting OAVs $<1$ might also contribute to wine aroma (Sanchez-Palomo et al., 2010). We found 17 odour-active volatiles with OAVs $>1$ (Table 3 ), so with OAVs greater than 50, ethyl octanoate, isoamyl acetate, ethyl hexanoate, and ethyl butanoate could be responsible for the aroma in Merlot wines, which supports previous studies of Merlot wine aroma.

Table 3. Odour activity values ${ }^{\mathrm{a}}$ of the aromatic compounds in wines from berries of different FZs $\mathrm{s}^{\mathrm{b}}$ on the vine of 2 grape cultivars.

\begin{tabular}{|c|c|c|c|c|c|c|c|c|c|c|}
\hline \multirow{2}{*}{ Code } & \multirow{2}{*}{ Compound } & \multirow{2}{*}{$\begin{array}{c}\begin{array}{c}\text { Odour } \\
\text { threshold }\end{array} \\
(\mu \mathrm{g} / \mathrm{L})\end{array}$} & \multirow{2}{*}{$\begin{array}{c}\text { Odour } \\
\text { description }\end{array}$} & \multirow{2}{*}{$\begin{array}{c}\text { Odorant } \\
\text { Series }^{c}\end{array}$} & \multicolumn{3}{|c|}{$\operatorname{Merlot}(\mu \mathrm{g} / \mathrm{L})$} & \multicolumn{3}{|c|}{ Chardonnay $(\mu \mathrm{g} / \mathrm{L})$} \\
\hline & & & & & $\mathrm{FZ1}$ & $\mathrm{FZ2}$ & FZ3 & $\mathrm{FZ1}$ & $\mathrm{FZ2}$ & FZ3 \\
\hline V1 & 1-Pentanol & 80000 & $\begin{array}{l}\text { Fruity, } \\
\text { balsamic }\end{array}$ & 1,3 & $1.00 \pm 0.01 \mathrm{a}^{\mathrm{d}}$ & $1.32 \pm 0.01 \mathrm{a}$ & $1.06 \pm 0.32 \mathrm{a}$ & $\mathrm{ND}^{\mathrm{e}}$ & $\mathrm{ND}$ & ND \\
\hline $\mathrm{V} 4$ & $\begin{array}{l}\text { Phenylethyl } \\
\text { Alcohol }\end{array}$ & 14000 & Sweet rose & 7,6 & $0.45 \pm 0.01 \mathrm{a}$ & $0.33 \pm 0.01 b$ & $0.33 \pm 0.03 b$ & $3.54 \pm 0.45 \mathrm{~A}$ & $3.42 \pm 0.45 \mathrm{~A}$ & $3.72 \pm 0.01 \mathrm{~A}$ \\
\hline V5 & Isopentanol & 30000 & $\begin{array}{l}\text { Alcohol, } \\
\text { harsh, bitter }\end{array}$ & 4 & $\mathrm{ND}$ & $\mathrm{ND}$ & $\mathrm{ND}$ & $1.23 \pm 0.00 \mathrm{~A}$ & $1.75 \pm 0.31 \mathrm{~A}$ & $1.62 \pm 0.61 \mathrm{~A}$ \\
\hline V6 & Ethyl Acetate & 7500 & Fruity, sweet & $1,3,4$ & $6.45 \pm 0.42 \mathrm{a}$ & $5.85 \pm 0.42 a$ & $6.72 \pm 0.54 a$ & $3.15 \pm 0.01 B$ & $4.92 \pm 0.06 \mathrm{~A}$ & $4.44 \pm 0.36 \mathrm{~A}$ \\
\hline V7 & $\begin{array}{l}\text { Isoamyl } \\
\text { acetate }\end{array}$ & 30 & Fresh, banana & 1 & $157.50 \pm 1.02 \mathrm{~b}$ & $175.62 \pm 1.02 \mathrm{a}$ & $158.25 \pm 1.14 b$ & $\mathrm{ND}$ & $\mathrm{ND}$ & $\mathrm{ND}$ \\
\hline V8 & Hexyl acetate & 670 & $\begin{array}{l}\text { Pleasant fruity, } \\
\text { pear }\end{array}$ & 1 & $1.30 \pm 0.03 \mathrm{a}$ & $1.09 \pm 0.03 b$ & $0.98 \pm 0.03 c$ & $\mathrm{ND}$ & $\mathrm{ND}$ & ND \\
\hline V9 & $\begin{array}{l}\text { Phenethyl } \\
\text { acetate }\end{array}$ & 250 & Pleasant, floral & 7 & $2.57 \pm 0.06 a$ & $2.13 \pm 0.03 b$ & $1.76 \pm 0.02 c$ & $1.11 \pm 0.06 \mathrm{~A}$ & $0.95 \pm 0.34 \mathrm{~A}$ & $1.14 \pm 0.04 \mathrm{~A}$ \\
\hline V10 & $\begin{array}{l}\text { Ethyl } \\
\text { butanoate }\end{array}$ & 20 & $\begin{array}{l}\text { Sour fruit, } \\
\text { strawberry, } \\
\text { fruity }\end{array}$ & 1 & $52.92 \pm 13.53 a$ & $49.08 \pm 13.53 a$ & $55.02 \pm 2.34 \mathrm{a}$ & $16.53 \pm 8.04 \mathrm{~A}$ & $12.75 \pm 2.97 \mathrm{~A}$ & $12.27 \pm 2.40 \mathrm{~A}$ \\
\hline V11 & $\begin{array}{l}\text { Ethyl } \\
\text { hexanoate }\end{array}$ & 5 & $\begin{array}{l}\text { Green } \\
\text { apple, fruity, } \\
\text { strawberry }\end{array}$ & 1,3 & $66.86 \pm 0.34 b$ & $61.19 \pm 0.34 c$ & $69.51 \pm 1.01 \mathrm{a}$ & $26.95 \pm 2.35 \mathrm{~A}$ & $24.88 \pm 3.28 \mathrm{~A}$ & $29.36 \pm 0.25 \mathrm{~A}$ \\
\hline V12 & $\begin{array}{l}\text { Ethyl } \\
\text { octanoate }\end{array}$ & 2 & $\begin{array}{l}\text { Pineapple, } \\
\text { pear, floral }\end{array}$ & 1,7 & $205.90 \pm 0.45 a$ & $158.15 \pm 0.45 c$ & $190.53 \pm 0.23 b$ & $71.35 \pm 0.38 \mathrm{~B}$ & $67.68 \pm 0.08 \mathrm{C}$ & $73.25 \pm 0.98 \mathrm{~A}$ \\
\hline V15 & $\begin{array}{l}\text { Ethyl } \\
\text { cinnamate }\end{array}$ & 1.1 & $\begin{array}{l}\text { Strawberry, } \\
\text { cream, cherry, } \\
\text { plum, } \\
\text { sweet, fruity, } \\
\text { honey }\end{array}$ & $3,6,5$ & $4.80 \pm 0.07 b$ & $3.13 \pm 0.07 \mathrm{c}$ & $7.28 \pm 0.17 \mathrm{a}$ & $\mathrm{ND}$ & $\mathrm{ND}$ & $\mathrm{ND}$ \\
\hline V27 & $\begin{array}{l}\text { Hexanoic } \\
\text { acid }\end{array}$ & 3000 & Cheese, rancid & 2 & $1.55 \pm 0.08 \mathrm{a}$ & $1.52 \pm 0.08 \mathrm{a}$ & $1.56 \pm 0.19 a$ & $1.06 \pm 0.01 \mathrm{~A}$ & $1.10 \pm 0.14 \mathrm{~A}$ & $1.19 \pm 0.09 \mathrm{~A}$ \\
\hline V28 & $\begin{array}{l}\text { Octanoic } \\
\text { Acid }\end{array}$ & 500 & $\begin{array}{l}\text { Rancid, harsh, } \\
\text { cheese, fatty } \\
\text { acid }\end{array}$ & 2 & $34.44 \pm 5.22 \mathrm{a}$ & $33.39 \pm 5.22 \mathrm{a}$ & $32.04 \pm 1.11 \mathrm{a}$ & $13.89 \pm 10.08 \mathrm{~A}$ & $18.81 \pm 1.11 \mathrm{~A}$ & $23.19 \pm 0.24 \mathrm{~A}$ \\
\hline V37 & Citronellol & 100 & Green lemon & 1 & $0.98 \pm 0.08 \mathrm{a}$ & $1.16 \pm 0.04 a$ & $1.57 \pm 0.27 \mathrm{a}$ & $\mathrm{ND}$ & $\mathrm{ND}$ & $\mathrm{ND}$ \\
\hline V38 & Linalool & 25.2 & Fruity, citric & $1,6,7$ & $4.68 \pm 0.30 \mathrm{a}$ & $0.27 \pm 0.30 \mathrm{~b}$ & $1.23 \pm 0.36 b$ & ND & ND & $\mathrm{ND}$ \\
\hline V39 & Farnesol & 1000 & $\begin{array}{l}\text { Lemon, anise, } \\
\text { floral, peach, } \\
\text { honey, pollen, } \\
\text { raspberry }\end{array}$ & $2,7,5$ & ND & $\mathrm{ND}$ & ND & $6.42 \pm 2.34 \mathrm{~A}$ & $5.28 \pm 0.28 \mathrm{~A}$ & $5.62 \pm 1.00 \mathrm{~A}$ \\
\hline V40 & $\begin{array}{l}\text { Beta- } \\
\text { damascenone }\end{array}$ & 0.05 & $\begin{array}{l}\text { Apple, rose, } \\
\text { honey }\end{array}$ & 1,6 & $1.35 \pm 0.00 \mathrm{a}$ & $\mathrm{ND}$ & $\mathrm{ND}$ & $281.25 \pm 13.76 \mathrm{~A}$ & $167.55 \pm 16.68 \mathrm{~B}$ & $157.08 \pm 10.08 \mathrm{~B}$ \\
\hline
\end{tabular}

${ }^{a}$ Values are expressed as the mean \pm standard deviation of the triplicate samples; ${ }^{\mathrm{b}} \mathrm{FZs}$, fruit-zones: FZ1, $140-200 \mathrm{~cm}$ above the ground; FZ2:80-140 $\mathrm{cm}$; FZ3:20-80 cm; ${ }^{\mathrm{C}} 1$ : fruity, 2 : fatty, 3: spicy, 4: solvent, 5: herbaceous, 6: sweet, 7: floral; ${ }^{\mathrm{d}}$ Different letters in the same row indicate significant differences determined by ANOVA (P < 0.05): a, b, c for Merlot, $\mathrm{x}, \mathrm{y}, \mathrm{z}$ for Cabernet Sauvignon and A, B, C for Chardonnay; ${ }^{\mathrm{e}}$ ND: not detected. 

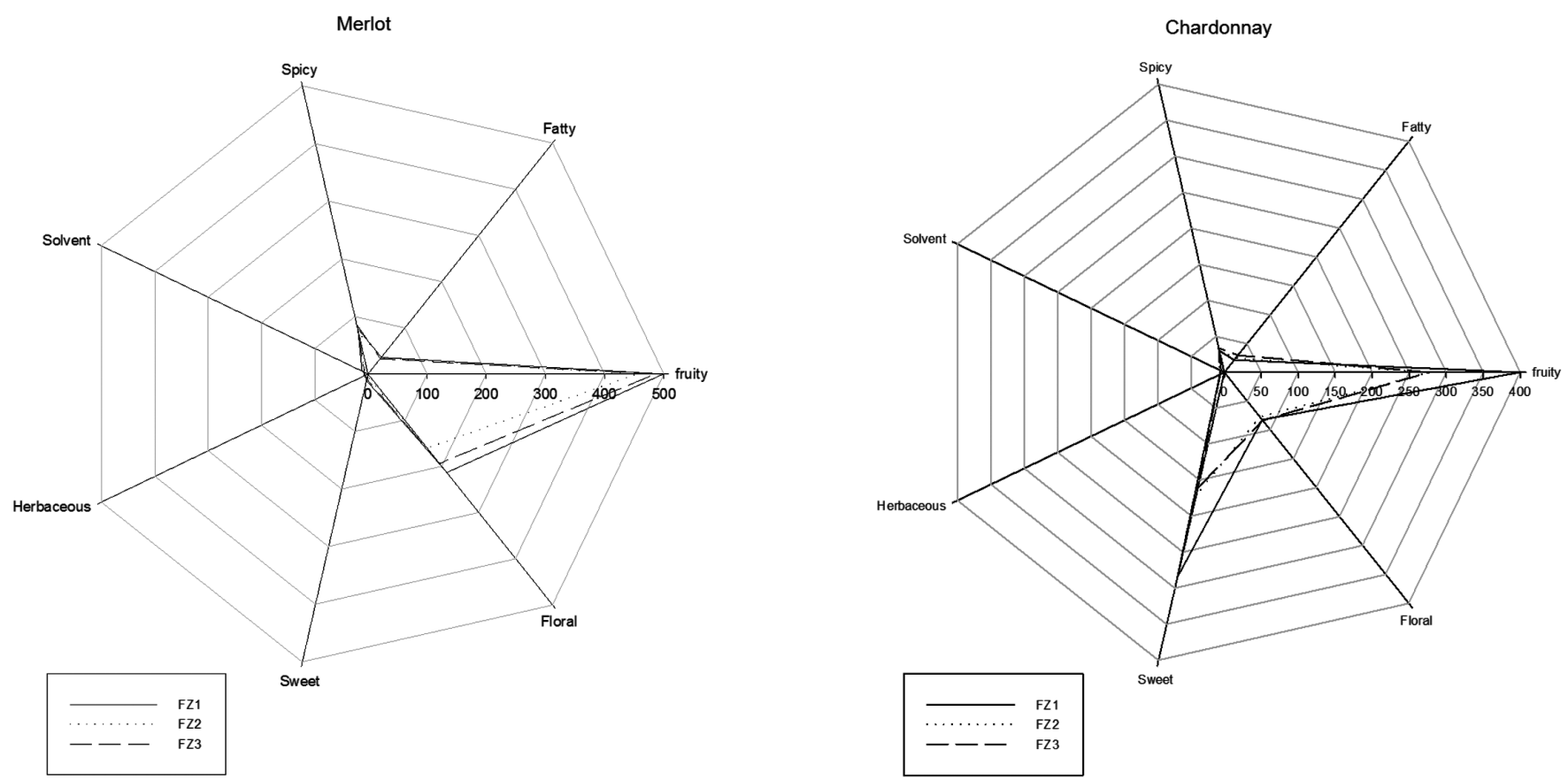

Figure 3. The intensity of the aromatic series in wines from the different fruit zones (FZ1: 140-200 cm above the ground; FZ2:80-140 cm; FZ3: $20-80 \mathrm{~cm}$ ) of 2 grape varieties. The intensity of each aromatic series is calculated as the sum of the OAVs of each volatile related to the series.

(Ferreira et al., 2000; Gurbuz et al., 2006) Furthermore, ethyl octanoate and ethyl hexanoate were found by ANOVA to be the most influential in differentiating among the Merlot wines from the various-height berries. As discussed above, the volatiles with the greatest capacity to produce differences in the various- FZ Merlot wines were fermentation-related volatile esters, and these differences might result from the differences in the nutrient density of the fermentative must. In the Chardonnay wines, the main aroma contributor was the beta-damascenone derived from the grapes, which is consistent with previous studies that have found that the characteristics of the aromas of white wines are strongly related to the presence of beta-damascenone (Selli et al., 2006; Genovese et al., 2007). Moreover, the highest beta-damascenone OAVs were found in the FZ1 wines; the increased sunlight and maturity in FZ1 might contribute to the accumulation of this compound (Gonzalez-Barreiro et al., 2014). Ethyl octanoate was another compound that contributed to the differences in the aroma of various-FZ Chardonnay wines.

To connect the quantitative volatile compound results with sensory perception, 17 odour-active volatiles were grouped into 7 aromatic series: fruity, fatty, spicy, solvent, herbaceous, sweet, and floral. The total intensities for every aromatic series were calculated as the sum of the OAVs of each volatile related to the series (Sanchez-Palomo et al., 2010) and the results are graphed in Figure 3. The major aroma characteristic of the Merlot wines was composed of the fruity and floral series, representing approximately $83 \%$ of the total aroma. Except for some distinctions in intensity, the aroma characters of the different- FZ wines were similar, and as expected, FZ1 wines of Merlot are more aromatic than the other $\mathrm{FZ}$ wines, with a total OAV of 854.94.
The various-FZ Merlot wines exhibited differences in floral and fruity series. In addition, the fruity, sweet and floral series were reported here to be significant contributors to Chardonnay wines, and fruity and sweet series were highly intense in the FZ1 wines, which was mainly attributed to the high beta-damascenone concentrations in the FZ1 wines of Chardonnay.

\section{Conclusions}

In our study, berry-height exerts significant influence on ethyl octanoate, isoamyl acetate, ethyl hexanoate, and ethyl butanoate in the various- FZ wines of Merlot and beta-damascenone in various- FZ Chardonnay wines. Consequently, the Merlot FZ1 wines were more aromatic than the other FZ wines and exhibited the highest floral and fruity series intensity. For the Chardonnay wines, fruity and sweet series were highly intense in the FZ1 wines. The PCA results demonstrated a high degree of aromatic differences between the various- FZ wines of both grape cultivars, especially Merlot cultivar, indicating the necessity of differentiating the wines from the various- FZ berries. Otherwise, mix of the different quality wines might result under uniform management. All of the study results could be useful to wineries considering the possibility of separating berries different- heights on the vine to produce wines of distinctive quality. Furthermore, this study open the way for evaluating the aroma potential of wines from berries taking into account their position along the vines.

\section{Acknowledgements}

This work was supported by the China Agriculture Research System for the Grape Industry (CARS-30-zp-9). 


\section{References}

Bell, S. J., \& Henschke, P. A. (2005). Implications of nitrogen nutrition for grapes, fermentation and wine. Australian Journal of Grape and Wine Research, 11(3), 242-295. http://dx.doi.org/10.1111/j.1755-0238.2005. tb00028.x.

Bindon, K., Varela, C., Kennedy, J., Holt, H., \& Herderich, M. (2013). Relationships between harvest time and wine composition in Vitis vinifera L. cv. Cabernet Sauvignon 1. Grape and wine chemistry. Food Chemistry, 138(2-3), 1696-1705. http://dx.doi.org/10.1016/j. foodchem.2012.09.146. PMid:23411300.

Bramley, R. G. V. (2005). Understanding variability in winegrape production systems - 2. Within vineyard variation in quality over several vintages. Australian Journal of Grape and Wine Research, 11(1), 33-42. http://dx.doi.org/10.1111/j.1755-0238.2005.tb00277.x.

Bramley, R. G. V., Ouzman, J., \& Boss, P. K. (2011). Variation in vine vigour, grape yield and vineyard soils and topography as indicators of variation in the chemical composition of grapes, wine and wine sensory attributes. Australian Journal of Grape and Wine Research, 17(2), 217-229. http://dx.doi.org/10.1111/j.1755-0238.2011.00136.x.

Buettner, A., \& Schieberle, P. (2001). Evaluation of aroma differences between hand-squeezed juices from valencia late and navel oranges by quantitation of key odorants and flavor reconstitution experiments. Journal of Agricultural and Food Chemistry, 49(5), 2387-2394. http:// dx.doi.org/10.1021/jf0013631. PMid:11368609.

Bureau, S. M., Razungles, A. J., \& Baumes, R. L. (2000). The aroma of Muscat of Frontignan grapes: effect of the light environment of vine or bunch on volatiles and glycoconjugates. Journal of the Science of Food and Agriculture, 80(14), 2012-2020. http://dx.doi.org/10.1002/10970010(200011)80:14<2012::AID-JSFA738>3.0.CO;2-X.

Cacho, J., Moncayo, L., Palma, J. C., Ferreira, V., \& Cullere, L. (2013). The impact of grape variety on the aromatic chemical composition of non-aromatic Peruvian pisco. Food Research International, 54(1), 373-381. http://dx.doi.org/10.1016/j.foodres.2013.07.019.

Cai, J., Zhu, B. Q., Wang, Y. H., Lu, L., Lan, Y. B., Reeves, M. J., \& Duan, C. Q. (2014). Influence of pre-fermentation cold maceration treatment on aroma compounds of Cabernet Sauvignon wines fermented in different industrial scale fermenters. Food Chemistry, 154, 217-229. http://dx.doi.org/10.1016/j.foodchem.2014.01.003. PMid:24518336.

Caliari, V., Panceri, C. P., Rosier, J. P., \& Bordignon-Luiz, M. T. (2015). Effect of the Traditional, Charmat and Asti method production on the volatile composition of Moscato Giallo sparkling wines. Lwt-Food Science and Technology, 61(2), 393-400. http://dx.doi. org/10.1016/j.lwt.2014.11.039.

Cheng, G., Liu, Y., Yue, T.-X., \& Zhang, Z.-W. (2015). Comparison between aroma compounds in wines from four Vitis vinifera grape varieties grown in different shoot positions. Food Science and Technology (Campinas.), 35(2), 237-246. http://dx.doi.org/10.1590/1678-457X.6438.

Coelho, E., Rocha, S. M., Barros, A. S., Delgadillo, I., \& Coimbra, M. A. (2007). Screening of variety- and pre-fermentation-related volatile compounds during ripening of white grapes to define their evolution profile. Analytica Chimica Acta, 597(2), 257-264. http:// dx.doi.org/10.1016/j.aca.2007.07.010. PMid:17683737.

Coetzee, C., \& du Toit, W. J. (2012). A comprehensive review on Sauvignon blanc aroma with a focus on certain positive volatile thiols. Food Research International, 45(1), 287-298. http://dx.doi. org/10.1016/j.foodres.2011.09.017.

Ferreira, V., Lopez, R., \& Cacho, J. F. (2000). Quantitative determination of the odorants of young red wines from different grape varieties. Journal of the Science of Food and Agriculture, 80(11), 1659-1667.
http://dx.doi.org/10.1002/1097-0010(20000901)80:11<1659::AIDJSFA693>3.0.CO;2-6.

Figueiredo-Gonzalez, M., Cancho-Grande, B., Boso, S., Santiago, J. L., Martinez, M. C., \& Simal-Gandara, J. (2013). Evolution of flavonoids in Mouraton berries taken from both bunch halves. Food Chemistry, 138(2-3), 1868-1877. http://dx.doi.org/10.1016/j. foodchem.2012.11.083. PMid:23411319.

Francis, I. L., \& Newton, J. L. (2005). Determining wine aroma from compositional data. Australian Journal of Grape and Wine Research, 11(2), 114-126. http://dx.doi.org/10.1111/j.1755-0238.2005.tb00283.x.

Garde-Cerdán, T., Lorenzo, C., Lara, J. F., Pardo, F., Ancin-Azpilicueta, C., \& Salinas, M. R. (2009). Study of the evolution of nitrogen compounds during grape ripening. application to differentiate grape varieties and cultivated systems. Journal of Agricultural and Food Chemistry, 57(6), 2410-2419. http://dx.doi.org/10.1021/jf8037049. PMid:19228058.

Garde-Cerdán, T., Santamaria, P., Rubio-Bretón, P., Gonzalez-Arenzana, L., López-Alfaro, I., \& López, R. (2015). Foliar application of proline, phenylalanine, and urea to Tempranillo vines: effect on grape volatile composition and comparison with the use of commercial nitrogen fertilizers. Lwt-Food Science and Technology, 60(2), 684-689. http:// dx.doi.org/10.1016/j.lwt.2014.10.028.

Gatti, M., Garavani, A., Cantatore, A., Parisi, M. G., Bobeica, N., Merli, M. C., Vercesi, A., \& Poni, S. (2015). Interactions of summer pruning techniques and vine performance in the white Vitis vinifera cv. Ortrugo. Australian Journal of Grape and Wine Research, 21(1), 80-89. http://dx.doi.org/10.1111/ajgw.12107.

Genovese, A., Gambuti, A., Piombino, P., \& Moio, L. (2007). Sensory properties and aroma compounds of sweet Fiano wine. Food Chemistry, 103(4), 1228-1236. http://dx.doi.org/10.1016/j.foodchem.2006.10.027.

Goldberg, D. M., Karumanchiri, A., Soleas, G. J., \& Tsang, E. (1999). Concentrations of selected polyphenols in white commercial wines. American Journal of Enology and Viticulture, 50(2), 185-193.

Gomez-Miguez, M. J., Cacho, J. F., Ferreira, V., Vicario, I. M., \& Heredia, F. J. (2007a). Volatile components of Zalema white wines. Food Chemistry, 100(4), 1464-1473. http://dx.doi.org/10.1016/j. foodchem.2005.11.045.

Gomez-Miguez, M. J., Gomez-Miguez, M., Vicario, I. M., \& Heredia, F. J. (2007b). Assessment of colour and aroma in white wines vinifications: Effects of grape maturity and soil type. Journal of Food Engineering, 79(3), 758-764. http://dx.doi.org/10.1016/j.jfoodeng.2006.02.038.

Gonzalez-Barreiro, C., Rial-Otero, R., Cancho-Grande, B., \& SimalGandara, J. (2014). Wine Aroma Compounds in Grapes: A Critical Review. Critical Reviews in Food Science and Nutrition, 55(2), 202-218. http://dx.doi.org/10.1080/10408398.2011.650336. PMid:24915400.

Grifoni, D., Carreras, G., Zipoli, G., Sabatini, F., Dalla Marta, A., \& Orlandini, S. (2008). Row orientation effect on UV-B, UV-A and PAR solar irradiation components in vineyards at Tuscany, Italy. International Journal of Biometeorology, 52(8), 755-763. http://dx.doi. org/10.1007/s00484-008-0168-1. PMid:18594874.

Gurbuz, O., Rouseff, J. M., \& Rouseff, R. L. (2006). Comparison of aroma volatiles in commercial Merlot and Cabernet Sauvignon wines using gas chromatography - Olfactometry and gas chromatography - Mass spectrometry. Journal of Agricultural and Food Chemistry, 54(11), 3990-3996. http://dx.doi.org/10.1021/jf053278p. PMid:16719525.

Hernandez-Orte, P., Concejero, B., Astrain, J., Lacau, B., Cacho, J., \& Ferreira, V. (2015). Influence of viticulture practices on grape aroma precursors and their relation with wine aroma. Journal of the Science of Food and Agriculture, 95(4), 688-701. http://dx.doi.org/10.1002/ jsfa.6748. PMid:24852393. 
International Organisation of Vine and Wine - OIV. (2012). International standard or labelling wines. Retrieved from: http://www.oiv.int/oiv/ files/\%20-\%20Publications/5\%20-\%201\%20Publications\%20OIV/ EN/OIV\%20Wine\%20Labelling\%20Standard\%20EN_2012.pdf

International Organisation of Vine and Wine - OIV. (2014). Compendium of nternational methods of wine and must analysis. Retrieved from: http://www.oiv.int/oiv/files/Compendium_2014_EN_Volume1.pdf

Jiang, B., Xi, Z. M., Luo, M. J., \& Zhang, Z. W. (2013). Comparison on aroma compounds in Cabernet Sauvignon and Merlot wines from four wine grape-growing regions in China. Food Research International, 51(2), 482-489. http://dx.doi.org/10.1016/j.foodres.2013.01.001.

Keller, M., \& Hrazdina, G. (1998). Interaction of nitrogen availability during bloom and light intensity during veraison. II. Effects on anthocyanin and phenolic development during grape ripening. American Journal of Enology and Viticulture, 49(3), 341-349.

Li, H., Tao, Y. S., Wang, H., \& Zhang, L. (2008). Impact odorants of Chardonnay dry white wine from Changli County (China). European Food Research and Technology, 227(1), 287-292. http:// dx.doi.org/10.1007/s00217-007-0722-9.

López de Lerma, M. N., Bellincontro, A., García-Martínez, T., Mencarelli, F., \& Moreno, J. J. (2013). Feasibility of an electronic nose to differentiate commercial Spanish wines elaborated from the same grape variety. Food Research International, 51(2), 790-796. http:// dx.doi.org/10.1016/j.foodres.2013.01.036.

Meng, J. F., Xu, T. F., Song, C. Z., Li, X. L., Yue, T. X., Qin, M. Y., Fang, Y.-L., Zhang, Z.-W., \& Xi, Z.-M. (2013). Characteristic free aromatic components of nine clones of spine grape (Vitis davidii Foex) from Zhongfang County (China). Food Research International, 54(2), 1795-1800. http://dx.doi.org/10.1016/j.foodres.2013.09.039.

Meng, J. F., Xu, T. F., Song, C. Z., Yu, Y., Hu, F., Zhang, L., Zhang, Z. W., \& Xi, Z. M. (2015). Melatonin treatment of pre-veraison grape berries to increase size and synchronicity of berries and modify wine aroma components. Food Chemistry, 185, 127-134. http://dx.doi. org/10.1016/j.foodchem.2015.03.140. PMid:25952850.

Meyers, J. M., Sacks, G. L., \& Vanden Heuvel, J. E. (2013). Glycosylated aroma compound responses in 'riesling' wine grapes to cluster exposure and vine yield. HortTechnology, 23(5), 581-588.

Moyano, L., Zea, L., Moreno, J., \& Medina, M. (2002). Analytical study of aromatic series in sherry wines subjected to biological aging. Journal of Agricultural and Food Chemistry, 50(25), 7356-7361. http://dx.doi.org/10.1021/jf020645d. PMid:12452658.

Nan, L. J., Liu, L. Y., Zhao, X. H., Qiu, S., Wang, H., \& Li, H. (2013). Effect of alternative new pruning system and harvesting times on aroma compounds of young wines from Ecolly (Vitis vinifera) in a new grape growing region of the Weibei Plateau in China. Scientia Horticulturae, 162, 181-187. http://dx.doi.org/10.1016/j. scienta.2013.08.021.

Noguerol-Pato, R., Gonzalez-Barreiro, C., Cancho-Grande, B., Santiago, J. L., Martinez, M. C., \& Simal-Gandara, J. (2012). Aroma potential of Brancellao grapes from different cluster positions. Food Chemistry,
132(1), 112-124. http://dx.doi.org/10.1016/j.foodchem.2011.10.042. PMid:26434270.

Pardo, F., Salinas, M. R., Alonso, G. L., Navarro, G., \& Huerta, M. D. (1999). Effect of diverse enzyme preparations on the extraction and evolution of phenolic compounds in red wines. Food Chemistry, 67(2), 135-142. http://dx.doi.org/10.1016/S0308-8146(99)00080-1.

Pereira, G. E., Gaudillere, J. P., Pieri, P., Hilbert, G., Maucourt, M., Deborde, C., Moing, A., \& Rolin, D. (2006). Microclimate influence on mineral and metabolic profiles of grape berries. Journal of Agricultural and Food Chemistry, 54(18), 6765-6775. http://dx.doi. org/10.1021/jf061013k. PMid:16939338.

Perestrelo, R., Fernandes, A., Albuquerque, F. F., Marques, J. C., \& Camara, J. S. (2006). Analytical characterization of the aroma of Tinta Negra Mole red wine: Identification of the main odorants compounds. Analytica Chimica Acta, 563(1-2), 154-164. http:// dx.doi.org/10.1016/j.aca.2005.10.023. PMid:17386707.

Reynolds, A. G., Wardle, D. A., Cliff, M. A., \& King, M. (2004). Impact of training system and vine spacing on vine performance, berry composition, and wine sensory attributes of Seyval and Chancellor. American Journal of Enology and Viticulture, 55(1), 84-95.

Rocha, S. M., Coutinho, P., Barros, A., Delgadillo, I., \& Coimbra, M. A. (2007). Establishment of the varietal volatile profile of musts from white Vitis vinifera L. varieties. Journal of the Science of Food and Agriculture, 87(9), 1667-1676. http://dx.doi.org/10.1002/jsfa.2872.

Sanchez-Palomo, E., Garcia-Carpintero, E. G., Alonso-Villegas, R., \& Gonzalez-Vinas, M. A. (2010). Characterization of aroma compounds of Verdejo white wines from the La Mancha region by odour activity values. Flavour and Fragrance Journal, 25(6), 456-462. http://dx.doi. org/10.1002/ffj.2005.

Schreier, P., \& Jennings, W. G. (1979). Flavor composition of wines: a review. CRC Critical Reviews in Food Science and Nutrition, 12(1), 59-111. http://dx.doi.org/10.1080/10408397909527273. PMid:389563.

Selli, S., Canbas, A., Cabaroglu, T., Erten, H., \& Gunata, Z. (2006). Aroma components of cv. Muscat of Bornova wines and influence of skin contact treatment. Food Chemistry, 94(3), 319-326. http:// dx.doi.org/10.1016/j.foodchem.2004.11.019.

Song, J., Smart, R. E., Dambergs, R. G., Sparrow, A. M., Wells, R. B., Wang, H., \& Qian, M. C. (2014). Pinot Noir wine composition from different vine vigour zones classified by remote imaging technology. Food Chemistry, 153, 52-59. http://dx.doi.org/10.1016/j. foodchem.2013.12.037. PMid:24491699.

Swiegers, J. H., Bartowsky, E. J., Henschke, P. A., \& Pretorius, I. S. (2005). Yeast and bacterial modulation of wine aroma and flavour. Australian Journal of Grape and Wine Research, 11(2), 139-173. http://dx.doi.org/10.1111/j.1755-0238.2005.tb00285.x.

Zoecklein, B. W., Wolf, T. K., Pelanne, L., Miller, M. K., \& Birkenmaier, S. S. (2008). Effect of vertical shoot-positioned, smart-dyson, and Geneva double-curtain training systems on Viognier grape and wine composition. American Journal of Enology and Viticulture, 59(1), 11-21. 